\title{
Population Growth and Distribution of Diadema antillarum at Discovery Bay, Jamaica
}

\author{
Andrew J. Sellers, Laura O. Casey, Erin J. Burge* and Eric T. Koepfler
}

Department of Marine Science, Coastal Carolina University, Conway, SC 29526 USA

\begin{abstract}
The urchin Diadema antillarum Philippi (Echinodermata: Echinoidea) was extremely rare to absent from reefs throughout Jamaica during much of the 1980s and part of the 1990s following a Caribbean wide mortality event. This survey was conducted in 2007 to assess their distribution on the western forereef of Discovery Bay, Jamaica. Mean urchin densities of $3.93 \pm 3.4 \mathrm{~m}^{-2}$ (mean $\pm \mathrm{SD}$ ) are the highest that have been recorded in Discovery Bay since the mortality event. The increases in $D$. antillarum numbers of the past decade have been accompanied by reductions in macroalgal cover. This study found a strong inverse correlation (Pearson product-moment correlation $=-0.597, p<0.000$ ) between macroalgal cover and Diadema density, indicating that the urchins are exerting a strong top-down control on macroalgae. Any future increases in urchin densities will most likely result in further reductions of macroalgal cover.
\end{abstract}

Keywords: Diadema antillarum, Macroalgae, Discovery Bay, Jamaica, Population, Herbivore, Recovery, Grazer.

\section{INTRODUCTION}

Over the past thirty years Caribbean coral reefs have undergone a shift in dominance of primary producers, possibly caused by the marked decrease in the population of Diadema antillarum Philippi (Echinodermata: Echinoidea) [1]. A seminal study in Jamaica by Goreau [2] documented lush coral communities with densities comparable to those seen on the Great Barrier Reef. When Goreau's survey was conducted, huge tree-like colonies of Acropora palmata were common throughout the reef. More than $90 \%$ of the available surface of the buttress (mixed zone) was covered by living coral, and rich beds of A. cervicornis were found on the uppermost region of the seaward slope of the reef. In stark contrast to this, studies conducted during the 1990s on the west forereef at Discovery Bay, Jamaica showed percent coverage by coral had declined to $\leq 5 \%$ [3]. This coral decline was accompanied by dramatic increases in macroalgal cover (44-79\%) at the surveyed depths.

Disturbances which may have also contributed to coral community change include coral bleaching [4], overfishing of large herbivorous fish, and hurricanes Allen and Gilbert in the 1980s [5]. However a mass mortality of D. antillarum has been considered by many authors as one of the most significant causes for this phase shift [4-8].

Between 1983 and 1984 populations of D. antillarum suffered a catastrophic mortality event which affected the entire Caribbean basin except Barbados [1]. Before 1983, the mean populations of sea urchins at locations in Discovery Bay, Jamaica, were as high as 71 urchins $\mathrm{m}^{-2}$ [9], 10 urchins $\mathrm{m}^{-2}$ in the shallow buttress zone $(8 \mathrm{~m})$ and 4 urchins $\mathrm{m}^{-2}$ at $15 \mathrm{~m}$ [10]. Population densities of this urchin declined shar-

*Address correspondence to this author at the Department of Marine Science, Coastal Carolina University, Conway, SC 29526 USA; Tel: +011843-349-6491; Fax: +011-843-349-2545; E-mail: eburge @ coastal.edu. ply to nearly $0 \mathrm{~m}^{-2}$ at depths of $5-10 \mathrm{~m}$ in the forereef by 1983 [7]. By 1998, populations along the northern coast of the island had only recovered to $5-10 \%$ of their original densities [10]. To date, reports $[11,12]$ have documented partial recovery, but urchin densities remain low, especially at middepths in the forereef.

Diadema are a major grazer on macroalgae throughout the Caribbean, and the distribution of their food sources depends on their abundance on the reefs of the region. Previous studies on the feeding habits of the urchin $[13,14]$ have shown that they are attracted to fleshier species of macroalgae (e.g. Lobophora variegata). The urchins have shown low feeding preference to species containing metabolites which repel grazers (e.g. Sargassum sp., Dictyota sp.) and those species with highly calcified tissues (e.g. Halimeda sp. and Galaxaura sp.), although Sammarco [14] notes that Diadema grazing appeared to be most strongly related to proportional abundance of macroalgal community members and that food preference was not a major determinant of algal community structure.

The aim of this study was to describe the distribution of D. antillarum in comparison to past studies conducted in Discovery Bay, Jamaica, and to determine if urchin populations were continuing to increase, as has been reported by other researchers at Discovery Bay $[1,7,11,12,15,16]$. This study also compared the density of $D$. antillarum to macroalgal cover on the forereef.

\section{MATERIALS AND METHODS}

\section{Study Sites and Geographic Data}

Surveys were conducted in May 2007 within the western forereef of Discovery Bay, Jamaica. Discovery Bay is a semienclosed embayment located on the Jamaican north shore. It is protected from the ocean by a fringing reef which 
is swept by a slow east to west current. Jamaica usually experiences a mixed tidal range, with primarily diurnal spring tides, and low amplitude diurnal neaps. The tidal range recorded at the Discovery Bay Marine Lab ranged between $16-60 \mathrm{~cm}$ [17]. A boat channel which connects the bay to the ocean divides the reef into eastern and western sections. The bay has an areal extent of $\sim 1.4 \mathrm{~km}^{2}$ [17-19]. The town of Discovery Bay, a bauxite-processing plant and loading dock and the University of the West Indies, Discovery Bay Marine Lab, are located around the bay. The drainage basin is composed of porous limestone, while the bay itself has springs which are an input of fresher groundwaters [19], and these are thought to be significant sources of nitrates $[20,21]$.

\section{Data Collection}

Twelve $60 \mathrm{~m}$ parallel line transects were laid perpendicular to the reef crest along coral spur heads. Transects began at a mean water depth of $3.81 \pm 1.25 \mathrm{~m}$ (mean $\pm \mathrm{SD})$ and extended to a mean depth of $6.68 \pm 0.93 \mathrm{~m}$ (mean $\pm \mathrm{SD})$, with the deepest sample point at a depth of $8.23 \mathrm{~m}$ and the shallowest at $1.52 \mathrm{~m}$. Deeper locations were not surveyed as preliminary dives in the area indicated that Diadema antillarum were rare to absent below approximately $8 \mathrm{~m}$ (personal observations). The twelve transects were oriented along the upper surface of coral spurs ranging from the western edge of the channel entrance to Discovery Bay to 0.5 $\mathrm{km}$ to the west. Sites roughly corresponded to historic sampling locations from other studies [10, 11, 22], including Mooring 1 (M1), Dancing Lady, Long-term Study (LTS), and Caribbean Coastal Marine Productivity Program (CARICOMP). Observations were recorded every 6 meters along the transect line. At each sampling site a $1 \mathrm{~m}^{2} \mathrm{PVC}$ pipe quadrat was placed randomly to the left or right in relation to the line as dictated by values from a random number generator. In sites where no individuals were observed within the quadrat, yet a few individuals were seen near the edges, the sampling area was expanded to $2 \mathrm{~m}^{2}$ to obtain values of less than one Diadema $\mathrm{m}^{-2}$. The depth of the sampling site was recorded using an Aladin Smart Z nitrox dive computer (Scubapro Uwatec USA and Latin America, El Cajon, CA). Diadema density, per cent macroalgal cover, and macroalgae taxonomic composition within the quadrat $(n=130)$ were estimated at each site.

Mean and standard deviations of abundance of $D$. antillarum were determined by grouping by depth or by transect. Regression analysis was conducted in SigmaStat 3.11 (Systat Software, Inc., Chicago, IL) where $p \leq 0.05$ was considered significant, and the results graphically displayed using SigmaPlot 9.0 (Systat Software, Inc., Chicago, IL). Historical comparisons used the data of Liddell and Ohlhorst [7], Morrison [22], Cho and Woodley [23], Haley and Solandt [11], Moses and Bonem [10], and the present study.

\section{RESULTS}

\section{Diadema antillarum Densities and Abundance}

Among the 12 transects surveyed throughout the western forereef, the population densities of Diadema antillarum at all depths ranged from $0-15 \mathrm{~m}^{-2}$ with a mean density of 3.93 $\pm 3.4 \mathrm{~m}^{-2}$ (mean $\left.\pm \mathrm{SD}\right)$. The population densities by depth best fit a non-linear curve, although linear analysis revealed significant negative correlation between density and depth, as well (Pearson product-moment correlation $=-0.260, p=$ $0.003)$. Densities were very low in waters less than $2 \mathrm{~m}$ and increased rapidly to a peak from $3-5 \mathrm{~m}$. A rapid decrease in population density occurred after this depth (Fig. 1). The highest mean $D$. antillarum densities were found at a depth of $3 \mathrm{~m}$, while the lowest mean densities were found at $7 \mathrm{~m}$ (Table 1). There was a visibly apparent depth contour interval between 3 and $5 \mathrm{~m}$ in which Diadema were nearly

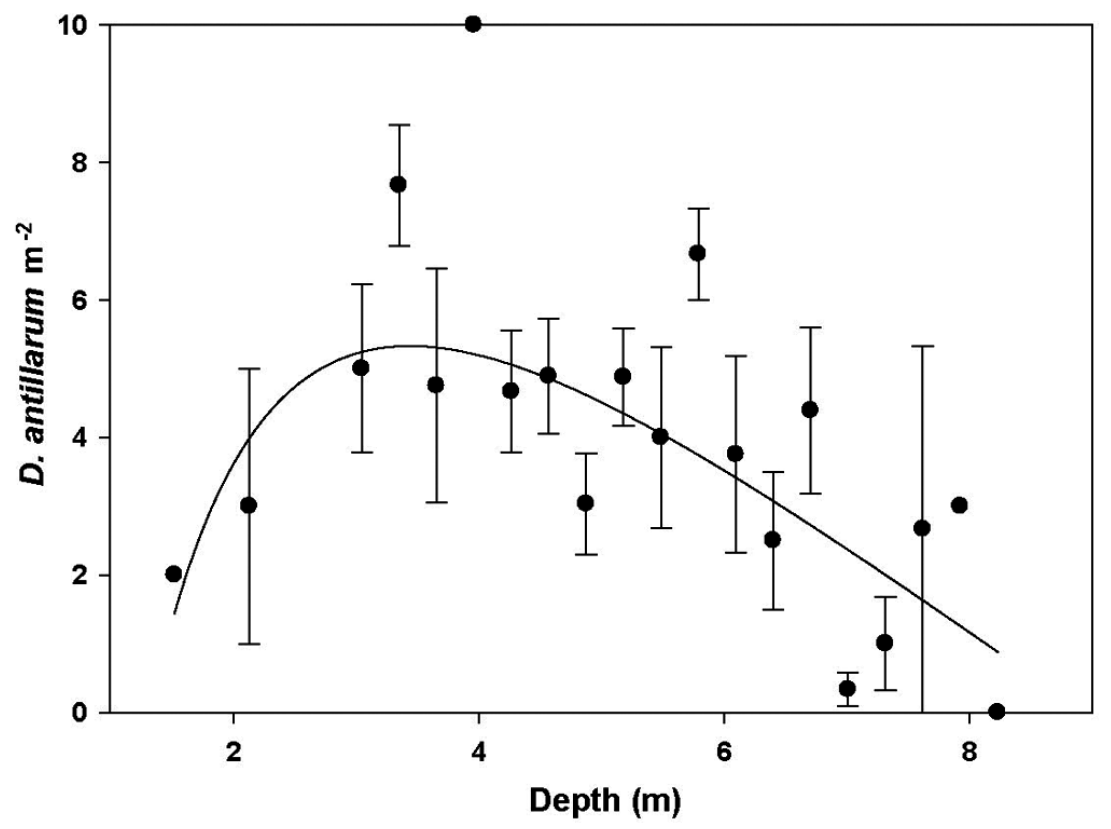

Fig. (1). Distribution of Diadema antillarum by depth. Closed circles represent urchin density as mean individuals $\mathrm{m}^{-2} \pm \mathrm{standard}$ error. Non linear regression $(p=0.0034)$ indicates a statistically significant relationship between urchin density and depth. 
Table 1. Descriptive Statistics for the Distribution of Diadema antillarum, and Macroalgal Cover by Depth

\begin{tabular}{|c|c|c|c|c|c|c|c|}
\hline $\begin{array}{c}\text { Depth } \\
\text { (m) }\end{array}$ & $\begin{array}{l}\text { D. antillarum Density } \\
(\text { mean } \pm \text { SD })\end{array}$ & $\begin{array}{l}\text { Max. } \\
\text { Density }\end{array}$ & $\begin{array}{c}\text { Min. } \\
\text { Density }\end{array}$ & $\begin{array}{c}\% \text { Macroalgal Cover } \\
(\text { mean } \pm \text { SD })\end{array}$ & $\begin{array}{c}\text { Max. \% } \\
\text { Cover }\end{array}$ & $\begin{array}{l}\text { Min. \% } \\
\text { Cover }\end{array}$ & $\mathbf{n}=$ \\
\hline 2 & $2.67 \pm 2.08$ & 5 & 1 & $17.33 \pm 28.29$ & 50 & 1 & 3 \\
\hline 3 & $5.64 \pm 2.73$ & 9 & 2 & $7.55 \pm 17.58$ & 60 & 0 & 12 \\
\hline 4 & $4.29 \pm 3.27$ & 12 & 0 & $10.75 \pm 18.33$ & 80 & 0 & 40 \\
\hline 5 & $4.77 \pm 3.39$ & 11 & 0 & $21.27 \pm 27.18$ & 99 & 1 & 33 \\
\hline 6 & $3.59 \pm 3.72$ & 15 & 0 & $29.63 \pm 27.87$ & 99 & 1 & 26 \\
\hline 7 & $1.07 \pm 2.23$ & 8 & 0 & $61.87 \pm 31.27$ & 99 & 1 & 14 \\
\hline \multirow[t]{2}{*}{8} & $1.50 \pm 2.12$ & 3 & 0 & $30 \pm 0$ & 30 & 30 & 2 \\
\hline & & & & & & & $\sum \mathrm{n}=130$ \\
\hline
\end{tabular}

Densities are given in individuals $\mathrm{m}^{-2}$ with maximum and minimum densities indicated. Macroalgal cover is given in per cent of hard substrate covered by macroalgae with maximum and minimum relative cover of replicate quadrats. Depth bins and their statistics are the result of combining all data collected between that depth and the next deeper depth bin (i.e.: data for $3 \mathrm{~m}$ includes densities and \% macroalgal cover between 3.00 and $3.99 \mathrm{~m}$ ). The depth bin for $2 \mathrm{~m}$ includes data collected at $1.52 \mathrm{~m}$.

always present. Urchins were rare to absent at depths less than or greater than this region.

\section{Macroalgal Cover and Distribution}

Macroalgal cover was strongly dependent on depth (Pearson product-moment correlation $=0.455, p<0.000$ ); as the depth increased so did macroalgal cover (Fig. 2). The lowest macroalgal cover values were consistently recorded in the shallowest regions of the reef, near the reef crest. The lowest mean percent cover was found at a depth of $3 \mathrm{~m}$, while the highest mean was found at $7 \mathrm{~m}$ (Table 1). Macroalgal dominance was strongest in the deeper sample areas $(6-8 \mathrm{~m})$ where mean macroalgal cover ranged between $29 \%$ and $60 \%$ of the hard substrate sampled (Table 1). As described for urchin abundances, a clearly demarcated depth region of high Diadema-low algae substrate was noted at all transects locations on the forereef.

This contrast in macroalgal cover between the shallow and deep sample points could be easily observed during the surveys. At a depth of approximately $5 \mathrm{~m}$ a marked boundary existed where on the shallow side cover was very low, while on the deeper side macroalgae covered a majority of the substrate sampled. The mean macroalgal percent cover did not exceed $65 \%$ for any depth, although certain sampling points reached values near $100 \%$ (Table 1).

Some depth dependent variation in the macroalgal species composition was observed. Sargassum sp. was one of the dominant species in the shallower areas $(2-4 \mathrm{~m})$ of the reef, but as depth increased other species became more common, including Lobophora sp., which was not seen at

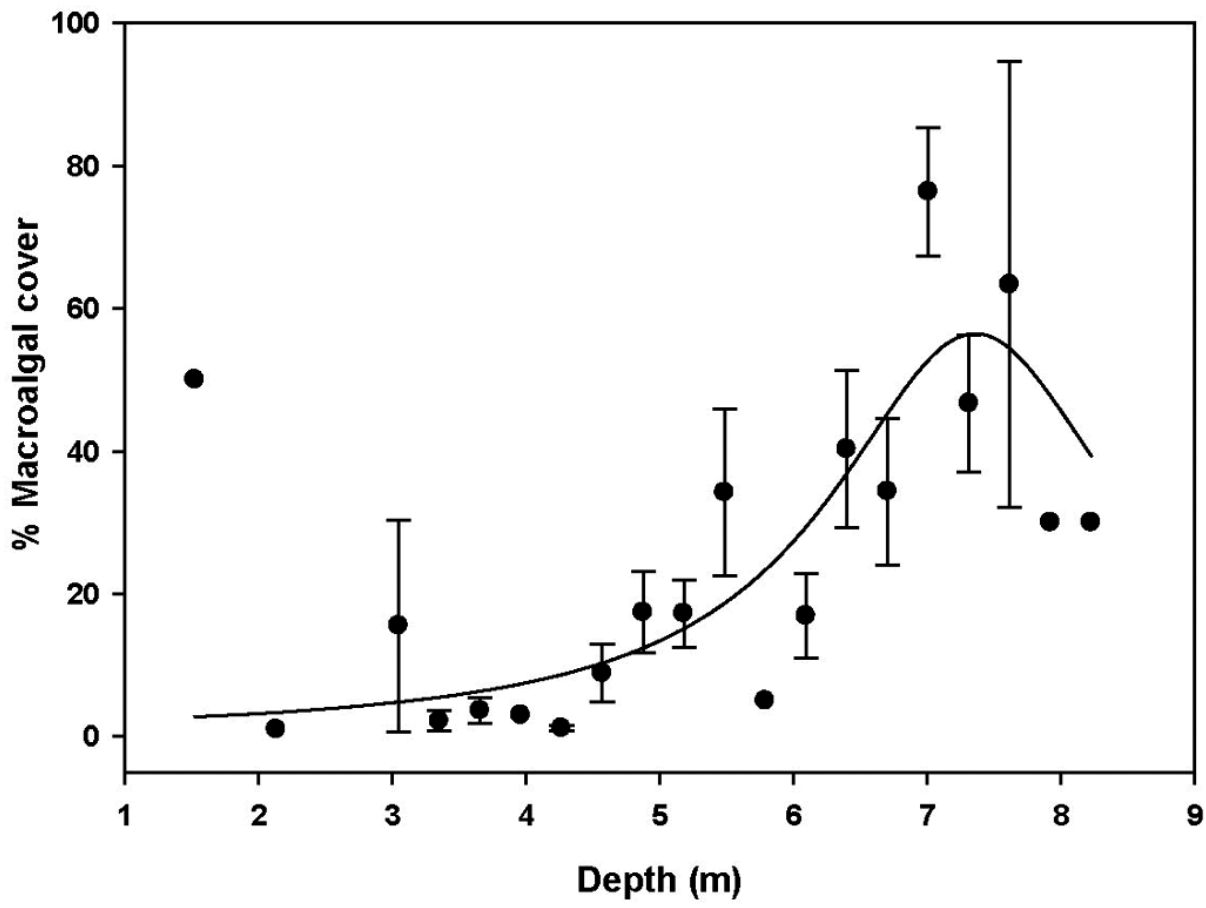

Fig. (2). Macroalgal cover over the substrate sampled by depth. Closed circles represent $\%$ macroalgal cover mean \pm standard error. Non linear regression $(p<0.001)$ indicates a statistically significant positive relationship between $\%$ macroalgal coverage and increasing depth. 
depths shallower than 5m, and Cladophora sp., which was not found at depths shallower than $6 \mathrm{~m}$.

\section{Algal Cover and Distribution in Relation with $D$. antillarum Densities}

A significant inverse relationship between the distribution of $D$. antillarum and macroalgal cover was observed (Pearson product-moment correlation $=-0.597, p<0.000)$. Diadema densities and macroalgal cover had a negative relationship, as urchin densities increased macroalgal cover decreased (Fig. 3). In the shallower regions (3-5m) where urchin densities were highest, macroalgal cover was reduced. As depth increased, densities of the echinoderm decreased and more substrate was dominated by macroalgae (Fig. 4). Comparisons between this 'urchin zone' at $3-5 \mathrm{~m}$ and the 'algal zone' $(2-3 \mathrm{~m}$ and $6-8 \mathrm{~m})$ revealed a significant difference in estimated macroalgal cover $(p<0.001)$. At sites where the population density of $D$. antillarum was high, the macroalgal cover was reduced. These associations occurred along both shore normal and perpendicular orientations. Diadema densities and macroalgal percent cover are depicted as least squares regression estimated values, and do not show depth or actual distance from the reef crest. There

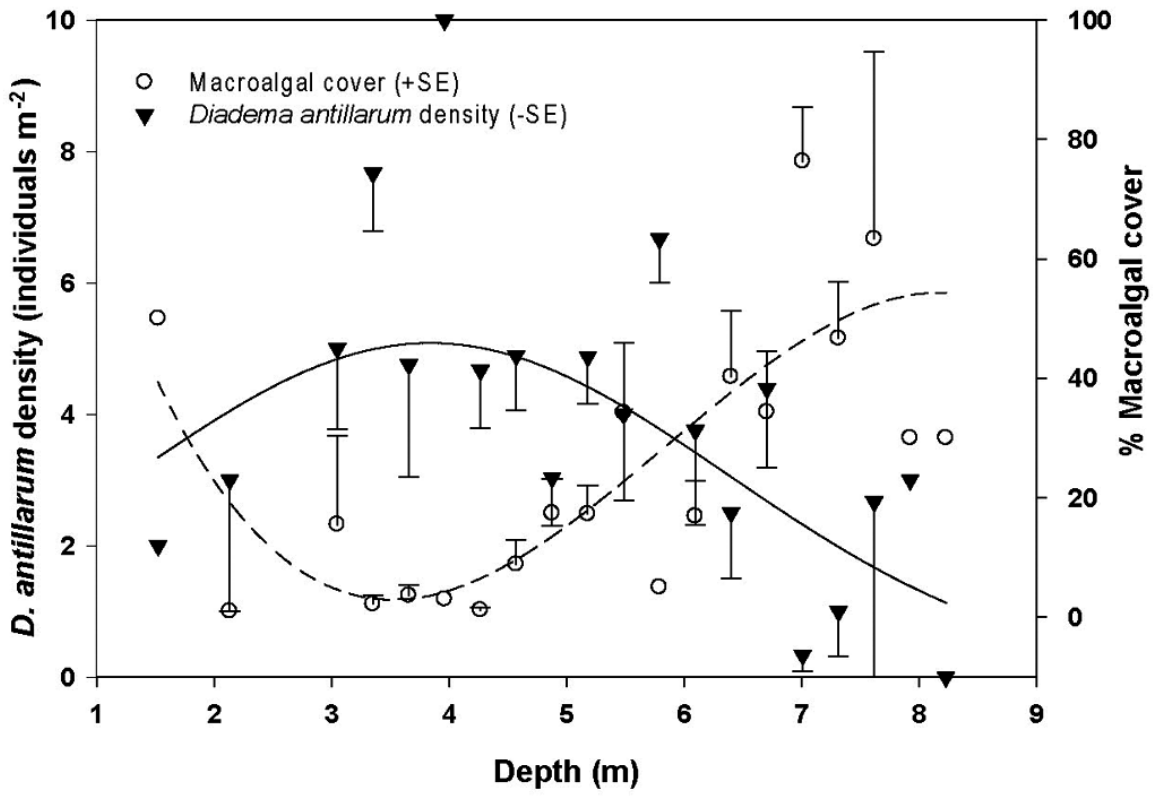

Fig. (3). Macroalgal cover as a function of Diadema antillarum population density. Macroalgal cover (open circles $\circ+$ SE; dotted line) as percentage of the substrate surveyed covered by macroalgae. Population densities (closed circles $\bullet$ - SE; solid line) are given as individuals $\mathrm{m}^{-2}$.

a)

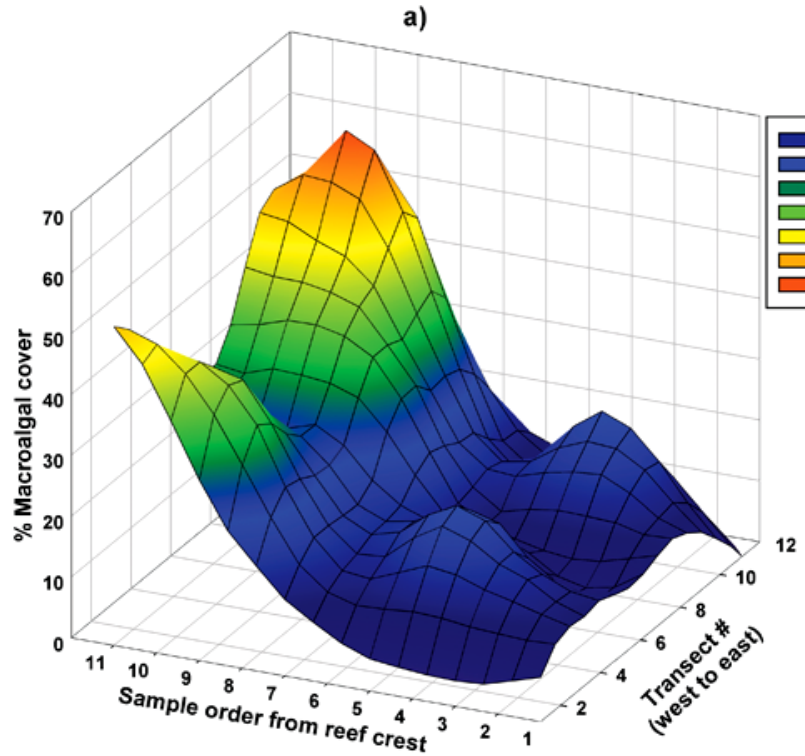

b)

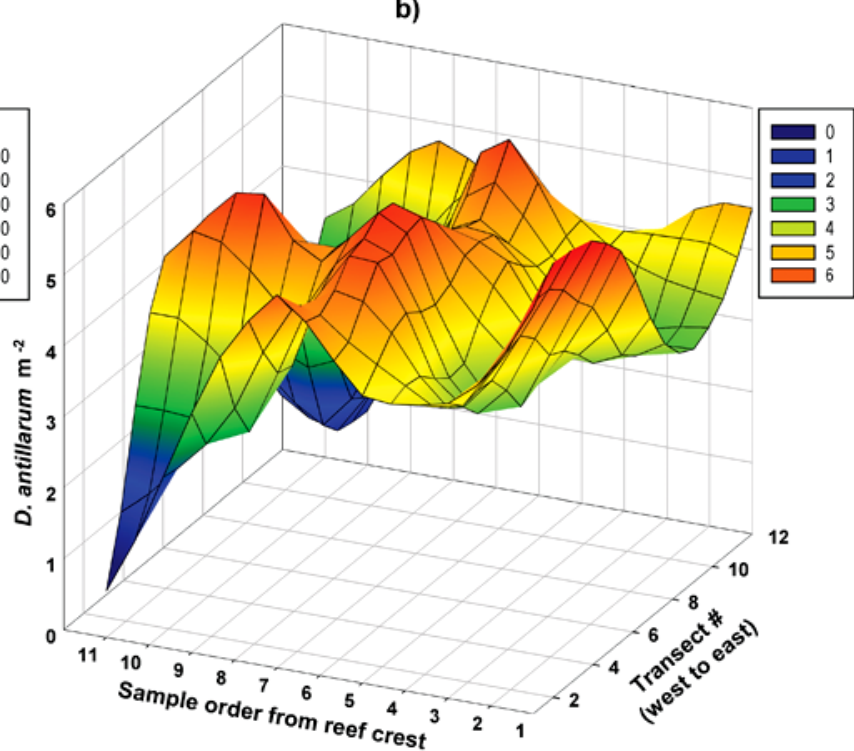

Fig. (4). a) Macroalgal percent cover as least squares regression estimated values by sample point. Surveys were taken every $6 \mathrm{~m}$. b) Diadema antillarum density means by sample point at $6 \mathrm{~m}$ intervals. 


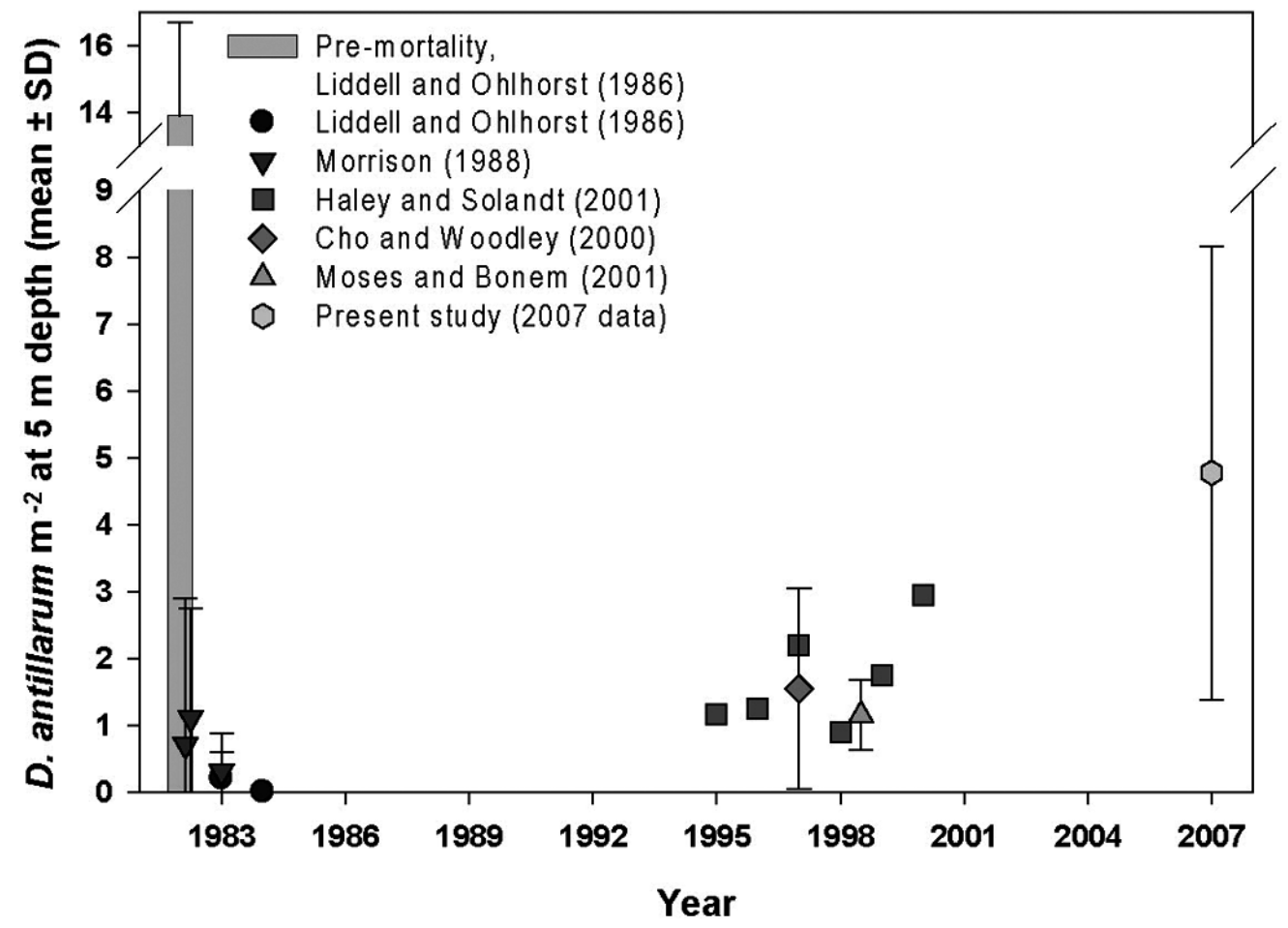

Fig. (5). Pre- and post-mortality density estimates of Diadema antillarum at $5 \mathrm{~m}$ on the west forereef at Discovery Bay, Jamaica. Actual sites vary between the studies but all sites were within $0.5 \mathrm{~km}$ of each other and located between the CARICOMP and Mooring 1 (M1) dive sites for all studies. Error bars are given when standard deviations (SD) were noted by the various authors. Morrison [22] measured Diadema densities immediately (1.5 and $3 \mathrm{mo}$ ) after the population collapse at Discovery Bay. Error bars from this study were calculated from the given standard error (SE) and sample sizes $(n)$ as $\left(\mathrm{SE}=\mathrm{SD}(\sqrt{ } \mathrm{n})^{-1}\right)$. Values for 1996, 1997, and 1998 were estimated from Fig. (1a) of Haley and Solandt [11]; values for 1999 and 2000 are given in the text. Error bars from Moses and Bonem [10] represent the calculated SD as $\sqrt{ }($ variance $)$, from data presented in the text. Regression of all post-mortality data $(1983-2007)$ indicates a significant population increase in D. antillarum $\left(p=0.0012 ; \mathrm{R}^{2}=0.707 ; \mathrm{y}=0.1637 \mathrm{x}-325.091\right)$.

was a significant correlation $\left(p<0.001, \mathrm{R}^{2}=0.55\right)$ between sample order from the transect origin and depth.

\section{Historical D. antillarum Densities and Slow Recovery of the Population}

Comparisons of historical data on Diadema densities from the western forereef of Discovery Bay and the present study from those same locations indicates that $D$. antillarum densities are increasing, but are not close to their pre-1983 numbers (Fig. 5). A historic time line of the urchin mortality and consequent return to the forereef at Discovery Bay was plotted by comparing densities reported by past studies to the values obtained in this survey. Linear regression of all postmortality data (1983-2007) indicates a significant population increase in D. antillarum $\left(p=0.0012 ; \mathrm{R}^{2}=0.707 ; \mathrm{y}=0.1637\right.$ $\mathrm{x}-325.091)$.

\section{DISCUSSION}

More than 25 years have passed since the catastrophic regional population collapse of Diadema antillarum [24]. This study supports others that have documented a partial recovery in the past two decades $[15,16]$, but these new data suggest that the rate of increase in population density has slowed in recent years. Diadema is considered a keystone herbivore on Caribbean coral reefs and adjacent habitats [1], and the impacts of the functional removal of this grazer are still particularly evident on the reefs of the north coast of Jamaica. In this study, we documented a highly significant relationship between slowly recovering Diadema densities and low macroalgal cover at Discovery Bay, Jamaica.

Trends in macroalgal cover and $D$. antillarum abundance (Table 2) show that increases in urchin density over the past decades have been coupled with a reduction in macroalgae $[3,7]$. Results from the present survey reveal that a strong correlation between macroalgal cover and $D$. antillarum distribution still exists. Just as reported in Edmunds and Carpenter [16], a high urchin density zone was observed during this survey. This high grazing zone formed a continuous contour at $3 \mathrm{~m}$ in which algal cover was noticeably low and high densities of $D$. antillarum were observed (Figs. 3 and 4). Edmunds and Carpenter [16] found this zone to be at depths between $5 \mathrm{~m}$ and $8 \mathrm{~m}$ in 2000 . The present study found that the zone has shifted to shallower depths in the forereef $(3-5 \mathrm{~m})$, although it is not known whether the location of the band is temporary or whether it fluctuates within a narrow range of depths. This zone of relatively high urchin abundance is in marked contrast to historical depth distributions from the north coast of Jamaica. Prior to the mass mortality, Liddell and Ohlhorst [7] reported high densities of Diadema $\left(6.6 \mathrm{~m}^{-2} \pm 1.9 \mathrm{SD}\right)$ extending to at least $15 \mathrm{~m}$ depth, and individuals were still common at $22 \mathrm{~m}\left(2.5 \mathrm{~m}^{-2} \pm 0.7 \mathrm{SD}\right)$. 
Table 2. Historic Timeline of Diadema antillarum Densities and Macroalgal Cover at $5 \mathbf{m}$ on the Western Forereef of Discovery Bay, Jamaica

\begin{tabular}{|c|c|c|c|c|c|}
\hline & $\mathbf{1 9 8 2}$ & $\mathbf{1 9 8 3}$ & $\mathbf{1 9 8 4}$ & $\mathbf{1 9 9 2}$ & $\mathbf{2 0 0 7}$ \\
\hline \hline \% Macroalgal cover (mean $\pm \mathrm{SD})$ & $17.6 \pm 6.5$ & $55.4 \pm 6.6$ & $72.7 \pm 10.0$ & $70.0 \pm 2.9$ & $21.3 \pm 18.2$ \\
\hline D. antillarum $\mathrm{m}^{-2}($ mean $\pm \mathrm{SD})$ & $13.9 \pm 2.8$ & $0.2 \pm 0.4$ & 0 & unknown & $4.8 \pm 3.4$ \\
\hline
\end{tabular}
this study.

Although these new data clearly indicate that $D$. antillarum densities are increasing, their recovery on the forereef of Discovery Bay may be slowing and appears to be confined to shallower depths than the species has historically occupied (personal observations). Mean population density doubled between 1995 and 2000 in the forereef [11]. In contrast, mean Diadema densities only increased by $0.98 \mathrm{~m}^{-2}$ in the seven years since the work of Haley and Solandt [11] and urchin densities observed within the Diadema zone during the present survey are very similar to those found by Edmunds and Carpenter [16]. The apparent decrease in the rate of recovery may very well be a sign that the urchin population may plateau in the coming years. Results of the 2007 study presented here suggested that the Diadema population on the forereef was very patchily distributed within preferred habitat. This is likely due to a combination of the patchy distribution of $D$. antillarum associated with daytime refugia [25] and their rapid decrease in population density with depth. As noted the high urchin density zone observed during this survey occurred primarily between 3-5 $\mathrm{m}$, but the overall density calculated $\left(3.93 \pm 3.4 \mathrm{~m}^{-2}\right)$ encompassed depths from $2-8 \mathrm{~m}$, thereby increasing the overall observed variation in the density estimate. Large standard deviations for Diadema density at $5 \mathrm{~m}$ in this study (Fig. 5) are likely the result of variations between transects where in some cases $5 \mathrm{~m}$ was within the high density urchin zone, and in others it was just outside this area.

Increases in density have been observed in other areas of the Caribbean as well. By 1985, just two years after the initial die-off took place, the densities of $D$. antillarum on reefs of Barbados had returned to values up to $57 \%$ of their pre-1983 populations [26]. Increases were also reported during the 1990s in Puerto Rico [27], and in Curacao [28]. Some increases have been more dramatic than others, but to this day populations have not yet made a full basin-wide recovery.

Other areas of the region have not seen any significant increase in Diadema populations that would indicate a recovery is taking place. In Panama, where the mortality was first observed and the population of Diadema has had more time to recover, their numbers still remained below $6.5 \%$ of their pre-mortality densities 20 years after the die-off event [29]. Similarly in the Florida Keys densities still have not experienced a recovery; in 1999, only 16 individuals were observed in an area spanning $200 \mathrm{~km} \mathrm{[30].}$

The variability in the population dynamics of $D$. antillarum throughout the Caribbean suggests that conditions that may encourage their recovery in some sites are not found in the sites where densities remain low. One possible explanation for the long-term depression of $D$. antillarum populations could be habitat loss. Diadema retreat into crevices during the day presumably to seek shelter from predation [11]. Before 1980 Acropora cervicornis and A. palmata dominated most of the forereef in Discovery Bay, and provided appropriate cover for the urchins to hide [31, 32]. However, much of this coral cover was destroyed by hurricanes Allen and Gilbert in 1980 and 1988 respectively $[5,17]$ leaving little shelter for the urchins. Reductions in coral cover resulted in a homogeneous environment dominated by macroalgae. Habitat complexity has been shown to attract $D$. antillarum, experimental studies showed that urchin presence and grazing on macroalgae increased in areas of the reef with higher habitat complexity [25]. In general acroporids across the Caribbean have been in retreat for many years [33]. This reduction in coral cover may have hindered the recovery of the urchins across the region.

In summary, although this study documented continuing growth in Diadema antillarum densities on the western forereef at Discovery Bay, Jamaica, the rate of this recovery seems to have slowed. This research, and that of others [16], documents a small spatial region of relatively high abundance for $D$. antillarum $(3-5 \mathrm{~m}$ depth in the case of this survey), although these urchins have not yet returned in appreciable numbers to deeper waters. Within their zone of high abundance, Diadema continue to be an important grazer on macroalgae, and have important impacts on benthic community structure. Several questions arise from the observations made during this survey and highlight the need for research to address ongoing population dynamics of Diadema and the potential for alternate phase shifts between coral and macroalgae dominated systems.

\section{ACKNOWLEDGEMENTS}

The authors wish to thank the staff of the Discovery Bay Marine Laboratory, University of the West Indies, for facilities support. Steven Luff, Scientific Dive Safety Officer, Coastal Carolina University and Samuel Lake, Coastal Carolina University, contributed to the completion of this study.

\section{REFERENCES}

[1] Lessios HA, Garrido MJ, Kessing BD. Demographic history of Diadema antillarum, a keystone herbivore on Caribbean reefs. Proc R Soc Lond B Biol Sci 2001; 268: 2347-53.

[2] Goreau TF. The ecology of Jamaican coral reefs I. Species composition and zonation. Ecology 1959; 40: 67-90.

[3] Andres NG, Witman JD. Trends in community structure on a Jamaican reef. Mar Ecol Prog Ser 1995; 118: 305-10. 
[4] Goreau TJ. Bleaching and reef community change in Jamaica: 1951-1991. Am Zool 1992; 32: 683-95.

[5] Hughes TP. Catastrophes, phase shifts, and large-scale degradation of a Caribbean coral reef. Science 1994; 265: 1547-51.

[6] Carpenter RC. Grazing by Diadema antillarum (Philippi) and its effects on the benthic algal community. J Mar Res 1981; 39: 74965.

[7] Liddell W, Ohlhorst S. Changes in community composition following the mass mortality of Diadema at Jamaica. J Exp Mar Biol Ecol 1986; 95: 271-8.

[8] Aronson RB, Precht WF. Herbivory and algal dynamics on the coral reef at Discovery Bay, Jamaica. Limnol Oceanogr 2000; 45: 251-5.

[9] Sammarco PW. Diadema and its relationship to coral spat mortality: grazing, competition, and biological disturbance. J Exp Mar Biol Ecol 1980; 45: 245-72.

[10] Moses CS, Bonem RM. Recent population dynamics of Diadema antillarum and Tripneustes ventricosus along the north coast of Jamaica, W. I. Bull Mar Sci 2001; 68: 327-36.

[11] Haley MP, Solandt J-L. Population fluctuations of the sea urchins Diadema antillarum and Tripneustes ventricosus at Discovery Bay, Jamaica: A case of biological succession? Caribb J Sci 2001; 37: 239-45.

[12] Mumby PJ, Hedley JD, Zychaluk K, Harborne AR, Blackwell PG. Revisiting the catastrophic die-off of the urchin Diadema antillarum on Caribbean coral reefs: Fresh insights on resilience from a simulation model. Ecol Model 2006; 196: 131-48.

[13] Solandt J-L, Campbell AC. Macroalgal feeding characteristics of the sea urchin Diadema antillarum Philippi at Discovery Bay, Jamaica. Caribb J Sci 2001; 37: 227-38.

[14] Sammarco PW. Effects of grazing by Diadema antillarum Philippi (Echinodermata: Echinoidea) on algal diversity and community structure. J Exp Mar Biol Ecol 1982; 65: 83-105.

[15] Carpenter RC, Edmunds PJ. Local and regional scale recovery of Diadema promotes recruitment of scleractinian corals. Ecol Lett 2006; 9: 271-80.

[16] Edmunds PJ, Carpenter RC. Recovery of Diadema antillarum reduces macroalgal cover and increases abundance of juvenile corals on a Caribbean reef. Proc Natl Acad Sci USA 2001; 98: 5067-71.

[17] Gayle PMH, Woodley JD. Discovery Bay, Jamaica. In: Kjerfve B, Ed. CARICOMP - Caribbean coral reef, seagrass and mangrove sites. Paris: UNESCO; 1998, pp. 17-33.

[18] Lapointe BE, Littler MM, Littler DS. Macroalgal overgrowth of fringing coral reefs at Discovery Bay, Jamaica: bottom-up versus top-down control. In: Lessios HA, MacIntyre IG, McGee M, Eds. Proceedings of the 8th International Coral Reef Symposium. Panama: Smithsonian Tropical Research Institute 1997; pp. 927-32.
[19] Lapointe BE. Nutrient thresholds for bottom-up control of macroalgal blooms on coral reefs in Jamaica and southeast Florida. Limnol Oceanogr 1997; 42: 1119-31.

[20] Greenaway AM, Gordon-Smith DA. The effects of rainfall on the distribution of inorganic nitrogen and phosphorus in Discovery Bay, Jamaica. Limnol Oceanogr 2006; 51: 2206-30.

[21] D'Elia FF, Webb KL, Porter JW. Nitrate-rich ground water inputs to Discovery Bay, Jamaica: A significant source of $\mathrm{N}$ to local coral reefs. Bull Mar Sci 1981; 31: 903-10.

[22] Morrison D. Comparing fish and urchin grazing in shallow and deeper coral reef algal communities. Ecology 1988; 69: 1367-82.

[23] Cho LL, Woodley JD. Recovery of reefs at Discovery Bay, Jamaica and the role of Diadema antillarum. Proceedings of the 9th International Coral Reef Congress. Bali, Indonesia 2000, pp. 331-7.

[24] Lessios HA, Robertson DR, Cubit JD. Spread of Diadema mass mortality through the Caribbean. Science 1984; 226: 335-7.

[25] Lee SC. Habitat complexity and consumer-mediated positive feedbacks on a Caribbean coral reef. Oikos 2006; 112: 442-7.

[26] Hunte W, Younglao D. Recruitment and population recovery of Diadema antillarum (Echinodermata; Echinoidea) in Barbados. Mar Ecol Prog Ser 1988; 45: 1-2.

[27] Weil E, Torres JL, Ashton M. Population characteristics of the sea urchin Diadema antillarum in La Parguera, Puerto Rico, 17 years after the mass mortality event. Rev Biol Trop 2005; 53 (Suppl 3): 219-31.

[28] Debrot AO, Nagelkerken I. Recovery of the long-spined sea urchin Diadema antillarum in Curaçao (Netherlands Antilles) linked to lagoonal and wave sheltered shallow rocky habitats. Bull Mar Sci 2006; 79: 415-24.

[29] Lessios HA. Diadema antillarum populations in Panama twenty years following mass mortality. Coral Reefs 2005; 24: 125-7.

[30] Chiappone M, Swanson DW, Miller SL, Smith SG. Large-scale surveys on the Florida Reef Tract indicate poor recovery of the long-spined sea urchin Diadema antillarum. Coral Reefs 2002; 21 . 155-9.

[31] Ogden JC, Carpenter RC. Species profiles: life histories and environmental requirements of coastal fishes and invertebrates (south Florida): long-spined black sea urchin. US Fish and Wildlife Service Biological Report 82(11.77), 1987; p. 17.

[32] Kaplan EH, Kaplan SL. A field guide to coral reefs of the Caribbean and Florida: a guide to the common invertebrates and fishes of Bermuda, the Bahamas, southern Florida, the West Indies, and the Caribbean coast of Central and South America. Boston: Houghton Mifflin Company 1982.

[33] Precht WF, Bruckner AW, Aronson RB, Bruckner RJ. Endangered acroporid corals of the Caribbean. Coral Reefs 2002; 21: 41-2.

(C) Sellers et al.; Licensee Bentham Open.

This is an open access article licensed under the terms of the Creative Commons Attribution Non-Commercial License (http://creativecommons.org/licenses/bync/3.0/), which permits unrestricted, non-commercial use, distribution and reproduction in any medium, provided the work is properly cited. 